Brooklyn Law School

BrooklynWorks

Faculty Scholarship

3-2021

Abolition as the Solution: Redress for Victims of Excessive Police Force

Alexis Hoag

Follow this and additional works at: https://brooklynworks.brooklaw.edu/faculty

Part of the Civil Rights and Discrimination Commons, and the Criminal Law Commons 


\title{
ABOLITION AS THE SOLUTION: REDRESS FOR VICTIMS OF EXCESSIVE POLICE FORCE
}

\author{
Alexis Hoag*
}

Introduction 721

I. An Attempt at Redress: The Civil Rights Act of 1866 .......... 726

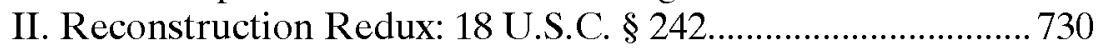

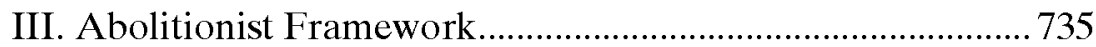

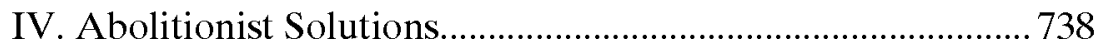

A. Reparations.................................................................. 739

B. Divest and Reinvest .................................................... 741

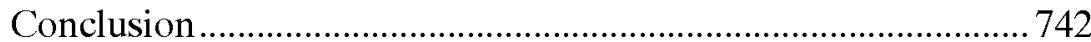

\section{INTRODUCTION}

Following the Civil War, tensions rose in Memphis, Tennessee. The City's racial demographics shifted dramatically, with thousands of freed Black people fleeing rural areas for the city center. Meanwhile, the law stripped former Confederates of their political positions, bringing the Irish into municipal power, ${ }^{1}$ many of whom held the freedmen in low regard. ${ }^{2}$ The freed people - formerly enslaved Black

* Associate research scholar and lecturer at Columbia Law School, Assistant Professor at Brooklyn Law School beginning July 2021. I would like to thank Amna Akbar, Daniel Harawa, Bernard Harcourt, and Kendall Thomas for their generative conversations and helpful feedback as I developed the ideas in this Essay, the participants in the faculty workshop at Columbia Law School for their suggestions, and Roger Tejada for his stellar research assistance.

1. See Hon. Bernice Bouie Donald, When the Rule of Law Breaks Down: Implications of the 1866 Memphis Massacre for the Passage of the Fourteenth Amendment, 98 B.U. L. REV. 1607, 1627-28 (2018).

2. See Memphis Riots and Massacres: The Official Report, DAILy MEMPHIS AVALANCHE, Dec. 5, 1866, at 1 (describing "feelings of hatred and revenge toward the colored race, which has been fostered by the Irish and by large numbers of people in 
men, women, and children, including Black soldiers - formed modest structures along the Mississippi River in and around Fort Pickering, which Union troops had overtaken during the war. ${ }^{3}$ Although Memphis was already home to an established free Black community, the City's Black population quadrupled post-war. The landscape changed to accommodate them, with the Freedmen's Bureau establishing Black schools and hospitals. ${ }^{4}$ A local paper derisively described the Bureau: "It is quite amusing to step in the office of the 'Bureau, - but not pleasant to the olfactories - and hear the pompous declamation and more pompous look and style of 'Cudjo' as he states his case ... [in] Africo-English[, a] wholesale murder of the language." 5 The City was like a powder keg waiting to explode.

On April 30, 1866, freedmen and white police officers clashed in South Memphis. According to one report, it began when "a Negro fell and a policeman stumbled over him. The police then drew their revolvers and attacked the Negroes, beating them with their pistols." The event unleashed four days of state-sanctioned violence against Black men, women, and children. On May 1, 1866, "the Negroes were hunted down by police, firemen and other white citizens, shot, assaulted, robbed, and in many instances their houses searched under the pretense of hunting for concealed arms, plundered, and then set on fire." 7 Over the next two days, "[a]ll crimes imaginable were committed [against the freedmen,] from simple larceny to rape and murder. Several [Black] women and children were shot in bed." 8

the South, ... hav[ing] . . intensified since the negro became free"); see also STEPHEN V. Ash, A Massacre in Memphis: The Race Riot That Shook the Nation One YEAR AFTER THE CIVIL WAR 179 (2013) (characterizing Irish "hatred" of freed Blacks as "intense").

3. See AsH, supra note 2, at 16 (describing Union troops occupying Fort Pickering).

4. See ERIC Foner, Reconstruction: AmERICA's UnFINISHED REVOLUTION, 1863-1877, at 262 (Henry Steele Commager \& Richard B. Harris eds., 2014) [hereinafter FONER, RECONSTRUCTION].

5. Police Court, Memphis Daily Argus, Apr. 29, 1866, at 3.

6. T.W. Gilbreth, The Freedmen's Bureau Report on the Memphis Race Riots of 1866 , TEACHING AM. Hist., https:/teachingamericanhistory.org/library/document/the-freedmens-bureau-report-o n-the-memphis-race-riots-of-1866 [https://perma.cc/DWH5-LE3Z] (last visited Jan. 27, 2021); see also The Memphis Massacre, CHI. TRIB., May 9, 1866, at 2 ("The riot seems to have been begun by three policemen hiring a white vagrant to 'pick a quarrel' with a colored boy of ten years of age. ... Some colored soldiers present, without violence, begged them not to shoot 'so small a boy,' and thereupon they killed four of the colored soldiers.").

7. Gilbreth, supra note 6.

8. Id. 
Subsequent investigation revealed that white municipal leaders instructed white Memphians to "get arms, organize and go through the Negro districts," imploring them to "kill every damned one of the n[***]er race and burn up the cradle." Reports estimated that white perpetrators - including law enforcement, City officials, and firemen - killed over 45 Black people, raped five Black women, and burned hundreds of Black homes, churches, and schools. ${ }^{10}$ Although scholars recognize that the Memphis Massacre - just one example of widespread violence against Black people after the Civil War ${ }^{11}$ helped lawmakers reconsider Reconstruction and eventually pass the Fourteenth Amendment, ${ }^{12}$ no one was held civilly or criminally liable for the atrocities. ${ }^{13}$

9. Id. (affidavit relaying the speech that City Recorder John C. Creighton delivered on May 1, 1866).

10. See, e.g., FONER, ReCONSTRUCTION, supra note 4, at 262; see also Gilbreth, supra note 6.

11. See Eoual Just. Initiative, Reconstruction in America: Racial VIOLENCE AFTER THE CIVIL WAR, 1865-1876, at 2 (2020), https://eji.org/report/reconstruction-in-america [https://perma.cc/ELD8-PQJK] ("Between 1865 and 1877, thousands of Black women, men, and children were killed, attacked, sexually assaulted, and terrorized by white mobs and individuals who were shielded from arrest and prosecution."); see also LEON F. LITWACK, BEEN IN THE STORM So Long: The AfTERmath OF SLAVERy 277 (1979) (stating that no "accurate body count or statistical breakdown [could] reveal the barbaric savagery and depravity that so frequently characterized the assaults made on freedmen in the name of restraining their savagery and depravity - the severed ears and entrails, the mutilated sex organs, the burnings at the stake, the forced drownings, the open display of skulls and severed limbs as trophies").

12. See, e.g., Donald, supra note 1, at 1640; see also Alexis Hoag, Valuing Black Lives: A Case for Ending the Death Penalty, 51 Colum. HuM. RTs. L. Rev. 985, 100103 (2020) (arguing that reports of widespread violence against Black people in the former Confederate states led Congress to pass the Fourteenth Amendment, in part, to provide redress to Black victims of crime).

13. See AsH, supra note 2, at 176 (describing the lack of legal action taken against those responsible for the massacre); see also Jin Hee Lee \& Sherrilyn A. Ifill, Do Black Lives Matter to the Courts?, in POLICING THE BLACK MAN 255, 256 (Angela J. Davis ed., 2017) (noting that the law has repeatedly failed to hold "law enforcement officers who have used excessive force on black bodies ... accountable"). In 2016, to mark the 150th anniversary of the Memphis Massacre, Black leaders requested the Tennessee Historical Commission erect a marker. But the state agency insisted on referring to it as a "race riot," which under a twentieth century understanding, implied that Black people were "rioting and destroying their community." See Christopher Blank, Do the Words 'Race Riot' Belong on a Historic Marker in Memphis?, NPR: All ThINGS CONSIDERED

(May

2, 2016), https://www.npr.org/sections/codeswitch/2016/05/02/476450908/in-memphis-a-divide-o ver-how-to-remember-a-massacre-150-years-later [https:/perma.cc/H9W4-M2BC]. The Black leaders revoked their request and raised private funds to erect a marker describing the event as a massacre. See id. 
Black victims of police violence still struggle to hold law enforcement officials accountable for excessive use of force, whether civilly or criminally. Some of the forces that prevent accountability include the government's difficulty in obtaining information to prosecute law enforcement officials; ${ }^{14}$ the latitude the law provides police officers to carry out their duties, including the use of lethal force, ${ }^{15}$ and the inherent conflicts that arise when prosecutors seek to charge the very people they rely on to supply evidence in cases they routinely prosecute. ${ }^{16}$ Impacting all of these factors is systemic racism, both in the institution of policing ${ }^{17}$ and in the carceral-focused criminal legal system. ${ }^{18}$ As the nation calls for a racial reckoning and large segments of the public demand an overhaul of the criminal legal system, ${ }^{19}$ the call to prosecute police officers presents a potential conflict.

14. See Dorothy E. Roberts, Constructing A Criminal Justice System Free of Racial Bias: An Abolitionist Framework, 39 Colum. Hum. RTs. L. REv. 261, 278-79 (2007) [hereinafter Roberts, Constructing a Criminal Justice System] (detailing legal rules, doctrines, and practices "that prevent victims [of police brutality] from obtaining relief in court").

15. See Graham v. Conner, 490 U.S. 386, 396-97 (1989) ("[C]alculus of reasonableness must embody allowance for the fact that police officers are often forced to make split-second judgments - in circumstances that are tense, uncertain, and rapidly evolving - about the amount of force that is necessary in a particular situation.").

16. See, e.g., Kate Levine, Who Shouldn't Prosecute the Police, 101 Iowa L. ReV. 1447, 1447 (2016) (describing conflict-of-interest when local prosecutors handle cases against police suspects); see also Roger A. Fairfax, Jr., The Grand Jury and Police Violence Against Black Men, in Policing the Black MAn 209, 223-28 (Angela J. Davis ed., 2017) (detailing "conflicts of interest inherent in prosecutions of law enforcement").

17. See, e.g., Brandon Hasbrouck, Abolishing Racist Policing with the Thirteenth Amendment, 68 UCLA L. REV. 200, 202 (2020) (describing policing as an anti-Black racist institution "designed to protect and serve the racial hierarchy").

18. See, e.g., Bryan Stevenson, A Presumption of Guilt: The Legacy of America's History of Racial Injustice, in Policing tHE BLACK MAN 3, 11 (Angela J. Davis ed., 2017) (explaining that after slavery, "states looked to the criminal justice system to construct policies and strategies to maintain white supremacy and racial subordination"); Allegra M. McLeod, Prison Abolition and Grounded Justice, 62 UCLA L. REV. 1156, 1185-86, 1193 (2015) (acknowledging the "history of slavery and Jim Crow's afterlife in criminal punishment practices," specifically uses of "criminal law administration as a central means of resisting the abolition of slavery, Reconstruction, and desegregation, continue to inform criminal processes and institutions to this day by enabling forms of brutality and disregard that would be unimaginable had they originated in other, more democratic, egalitarian, and racially integrated contexts").

19. See Larry Buchanan, Quoctrung Bui \& Jugal K. Patel, Black Lives Matter May Be the Largest Movement in U.S. History, N.Y. Times (July 3, 2020), https:/www.nytimes.com/interactive/2020/07/03/us/george-floyd-protests-crowd-size.h tml [https://perma.cc/85Y9-LJL7]. 
Following George Floyd's murder at the hands of Minneapolis police officers in May 2020, demonstrators demanded that officials arrest and criminally prosecute Derek Chauvin and the other officers involved. ${ }^{20}$ Demonstrators reacted in a similar fashion regarding the police officers who murdered Breonna Taylor in her Louisville, Kentucky, home in March 2020. ${ }^{21}$ At the same time, people were calling to defund the police, seeking to dismantle anti-Black racism in the criminal legal system, and advocating for a transition away from a carceral-focused paradigm. Yet, there is an inherent tension between abolishing the criminal legal system as it currently operates and demanding the criminal legal system deliver justice to Black victims of excessive use of police force. ${ }^{22}$ How can the very same law enforcement system that perpetuates anti-Black violence deliver justice to Black victims of law enforcement violence? As activist Mariame Kaba warned, "[i]f your concept of 'justice' means prison time for cops, then you should be despondent because this system as currently constituted almost NEVER delivers." 23 Indeed, the late Professor Derrick Bell urged us to accept "the reality that we live in a society in which racism has been internalized and institutionalized," a society that produced "a culture from whose inception racial discrimination has been a regulating force for maintaining stability and growth." 24 Armed with this understanding, those of us seeking redress must look outside of the existing infrastructure.

20. See Aviva Shen, Protesters Called Minneapolis Officials' Bluff on "Investigating" George Floyd's Killer, SLATE (May 29, 2020, 4:55 PM), https://slate.com/news-and-politics/2020/05/george-floyd-cops-indictment.html [https://perma.cc/IIB58-TZ24].

21. See Madeline Carlisle, 87 People Arrested During Breonna Taylor Protest Outside Kentucky Attorney General's Home, Time (July 15, 2020, 5:50 PM), https://time.com/5867132/breonna-taylor-kentucky-87-people-arrested-attorney-gene ral-cameron [https://perma.cc/58VE-BHME].

22. See, e.g., Amna Akbar, Toward a Radical Imagination of Law, 93 N.Y.U. L. REV. 405, 467 (2018) [hereinafter Akbar, Toward a Radical Imagination of Law] ("Protests and rebellions around the country have called on prosecutors to indict and prosecute police to the fullest extent of the law, invoking the under-enforcement argument: Prosecute the cops the way you prosecute us. Such a demand illuminates the double standards of the criminal system; it criminalizes minor crimes in Black communities while letting cops walk for murder. It also reveals debate and disagreement within the movement."); Kate Levine, Police Prosecutions and Punitive Instincts, 98 WASH. U. L. REV. (forthcoming 2021) ("There is an inherent tension between advocating for large scale reduction in the criminal legal footprint, while at the same time ratcheting up the system's harshness towards the police.").

23. Mariame Kaba, Prosecuting Cops Does Not Equal Justice, Truthout (May 6, 2015), https://truthout.org/articles/prosecuting-cops-does-not-equal-justice/ [https://perma.ce/QV33-WV2L].

24. Derrick Bell, Racism Is Here to Stay: Now What?, 35 How. L.J. 79, 88 (1991). 
This Essay examines the historical and present-day interpretations of a single federal criminal statute - the Civil Rights Act of 1866, a part of which became 18 U.S.C. $\$ 242$ - to argue that white supremacy prevents the criminal legal system from delivering justice to individual Black victims of state violence. This Essay argues that Black victims of state violence should instead seek abolitionist solutions to address and prevent systemic harm to Black communities. These arguments are part of a larger shift away from traditional criminal legal reform ${ }^{25}$ toward an anti-racist, anti-carceral, and anti-capitalist paradigm. ${ }^{26}$ As such, these arguments fit within an abolitionist framework. ${ }^{27}$

This Essay proceeds as follows: Part I examines the history of the Civil Rights Act of 1866, a Reconstruction statute aimed at federally prosecuting state actors for violating Black people's civil rights, to argue that the Act's related jurisprudence prevented meaningful redress to Black people. Part II reviews contemporary problems with the newer version of the statute, 18 U.S.C. $\$ 242$, which enables the Department of Justice (DOJ) to prosecute people acting under color of state law for violating citizens' civil rights. Part III explores the abolitionist framework as an avenue to pursue alternative solutions to harm. Part IV offers abolitionist solutions that have the potential to provide redress to whole communities that have experienced police violence. This Essay concludes with a call for reckoning with the nation's white supremacy to enable reconciliation.

\section{AN ATTEMPT AT REDRESS: THE CIVIL RIGHTS ACT OF 1866}

Reconstruction, which historian Eric Foner refers to as the nation's "Second Founding," sought to repair the fractured nation following the

25. These include calling for independent special prosecutors to investigate officer-involved fatalities and use of force cases. See, e.g., PrESIDENT's Task ForCE on 21st Century Policing, Final Report of the President's Task Force on 21st Century Policing 21 (2015).

26. See, e.g., Amna Akbar, An Abolitionist Horizon for (Police) Reform, 108 CALIF. L. Rev. 1781, 1843-44 (2020) [hereinafter Akbar, An Abolitionist Horizon] (rejecting traditional notions of police reform as not going "far enough" and calling instead for transformational change to "build and shift power [away from law enforcement], expand democratic domains, and demonstrate the potential for alternative political, economic, and social arrangements"); Jocelyn Simonson, Police Reform Through a Power Lens, 130 YALE L.J. 778, 803 (2021) ("[A]s legal scholars are increasingly recognizing the structural and historical problems inherent in our institutions of policing ... they are seeking out new, different, and sometimes more radical ways of envisioning police 'reform,' sometimes urging more popular influence, and at times questioning whether the police can be reformed at all.").

27. See infra Part III. 
Civil War and recognize Black people as citizens. ${ }^{28}$ Prior to Reconstruction, Black victims had few legal mechanisms were available to hold white perpetrators criminally liable. ${ }^{29}$ Early laws and evidentiary rules prevented Black enslaved people from testifying against white persons to determine guilt. ${ }^{30}$ Before Emancipation, criminal law generally did not recognize harmful acts committed against enslaved Black people as crimes. ${ }^{31}$ The legal invisibility of Black victims of crime had the potential to change during Reconstruction. ${ }^{32}$ In an expansion of the nation's founding documents, 33 the Reconstruction Amendments recognized Black people as citizens worthy of all of the "privileges and immunities" the Constitution guaranteed. ${ }^{34}$ The changing legal landscape recognizing Black citizens and codifying laws to protect them had the potential to transform the nation. Yet, obtaining criminal accountability continued to prove elusive despite laws recognizing conduct against Black people as criminal. ${ }^{35}$ Although Congress recognized "the need to authorize

28. See ERIC Foner, The Second Founding: How the Civil War and Reconstruction Remade the Constitution 67-68 (2019) [hereinafter Foner, SECOND FOUNDING].

29. See Hoag, supra note 12, at 996-99 (describing lack of legal redress available to Black victims of crime during slavery).

30. See A. Leon Higginbotham, Jr., In the Matter of Color: RaCE AND THE American Legal Process 58 (1978); Thomas D. Morris, Slaves and the Rules of Evidence in Criminal Trials, 68 CHI.-KENT L. REv. 1209, 1209 (1993) (describing evidentiary rules pertaining to enslaved people).

31. See Andrew Fede, Legitimized Violent Slave Abuse in the American South, 1619-1865: A Case Study of Law and Social Change in Six Southern States, 29 AM. J. LEGAL HisT. 93, 95 (1985) (describing pre-Emancipation legislation as "expressly depriv[ing] slaves who were violently abused by whites of the protections of the common law of crimes by passing exculpatory acts that granted both slave masters and whites who were strangers to the slave legal rights to beat, whip, and kill bondsmen").

32. See FONER, RECONSTRUCTION, supra note 4; see also Jamison v. MeClendon, 476 F. Supp. 3d 386, 397 (S.D. Miss. 2020) ("If the Civil War was the only war in our nation's history dedicated to the proposition that Black lives matter, Reconstruction was dedicated to the proposition that Black futures matter, too.").

33. See Scott v. Sanford, 60 U.S. 393 (1857) (finding that the Framers did not intend persons of African descent - whether enslaved or free - to be citizens of the United States within the meaning of the Constitution).

34. See U.S. Const. amend. XIV, $\$ 1$.

35. See, e.g., United States v. Cruikshank, 92 U.S. 542 (1875) (overturning convictions of white men who slaughtered several Black people because the indictment - secured under the Enforcement Act of 1870 - failed to allege racial animus). Originating out of Louisiana's Colfax Massacre of 1873, one of the most murderous acts of violence during Reconstruction wherein white people killed approximately 150 Black people, Cruiks hank represented the government's failed attempt to exert federal power over state crimes committed against Black citizens for attempting to exercise federal rights. See EOUAL JUST. INITIATIVE, supra note 11, at 90-91. 
enforcement, specify remedies, and create jurisdiction in the federal courts" in drafting legislation, it "underestimated the scale of the obstacles [it] faced in guaranteeing basic civil rights" to Black people. ${ }^{36}$ The main obstacle was white supremacy, on which the nation was founded and expanded upon, and which the former Confederate states, President Andrew Johnson, and the U.S. Supreme Court upheld. ${ }^{37}$

In April 1866, Congress passed the Civil Rights Act of 1866 over President Johnson's veto, ${ }^{38}$ enabling federal prosecution of state officials and private individuals who prevented Black people from enjoying freedom. ${ }^{39}$ Congress intended the Act to address the pervasive violence and mistreatment state actors directed at Black people attempting to exercise their civil rights. ${ }^{40}$ Prior to the war, the concept of civil rights was somewhat nebulous, but the new legislation provided a firmer legal meaning: " $[T]$ hose rights fundamental to being a free person." 41 However, the Act and other Reconstruction legislation framed civil rights in the negative rather than the positive.

36. George Rutherglen, Civil Rights in the Shadow of Slavery: The Constitution, Common Law, And THE Civil Rights Act OF 1866, at 15 (2013).

37. See, e.g., Foner, SECOND Founding, supra note 28, at 67-68 (describing President Johnson's hostility toward Black citizenship); FONER, RECONSTRUCTION, supra note 4, at 251 (noting pervasiveness of anti-Black racism in the nation during the Civil War era); Roberts, Constructing a Criminal Justice System, supra note 14, at 281 (explaining that white privilege and nonwhite disadvantage are embedded in contemporary policies and institutions based on the "racial hierarchies established in prior eras"); Nikole Hannah-Jones, Our Democracy's Founding Ideals Were False When They Were Written. Black Americans Have Fought to Make Them True., N.Y. TIMES MAG. (Aug. 14, 2019), https:/www.nytimes.com/interactive/2019/08/14/magazine/black-history-american-de mocracy.html [https:/perma.cc/4GRF-LVAY] ("Anti-black racism [derived from slavery] runs in the very DNA of this country ....").

38. See Dorothy E. Roberts, Abolition Constitutionalism, 133 HARv. L. REV. 1, 63 (2019) [hereinafter Roberts, Abolition Constitutionalism].

39. Senator Lyman Trumbull, Chairman of the Senate Judiciary Committee, introduced Section 2 as the "machinery to carry" Section 1 of the Act "into effect," explaining,

[t|hat any person who under color of any law, statute, ordinance, regulation, or custom, shall subject or cause to be subjected any inhabitant of any State or Territory to the deprivation of any right secured or protected by this act, or to different punishment, pains, or penalties on account of such person having at any time been held in a condition of slavery or involuntary servitude, . . . or by reason of his color or race, than is prescribed for the punishment of white persons, shall be deemed guilty of a misdemeanor, and on conviction shall be punished by fine not exceeding $\$ 1,000$, or imprisonment not exceeding one year, or both, in the discretion of the court.

Cong. Globe, 39th Cong., 1st Sess. 475 (1866).

40. See id.

41. FONER, SECOND FOUNDING, supra note 28, at 63. 
The Framers did not bestow new rights upon Black people, but rather removed race - and status as a formerly enslaved person - as a barrier to citizenship and then prohibited others from preventing citizens from exercising their civil rights.

The Reconstruction Framers' conception of civil rights - which implicated federalism - proved difficult to navigate in the fractured nation. Reflecting on Reconstruction legislation, Frederick Douglass observed that " $[t]$ he arm of the Federal government is long, but it is far too short to protect the rights of individuals in the interior of distant States." 42 The Civil Rights Act of 1866 required buy-in from the federal officials to prosecute people who violated Black people's rights and from the federal appellate courts to uphold lawfully secured convictions. The first case to test the reach of the Civil Rights Act's federal authority was Blyew v. United States. ${ }^{43}$

On August 29, 1868, in Kentucky, John Blyew and George Kennard, two white men, viciously slaughtered three generations of a Black family, the Fosters, with a broadaxe. ${ }^{44}$ The only witnesses were Black, including a grievously wounded victim who made a dying declaration identifying Blyew and Kennard as the assailants. ${ }^{45}$ Because a Kentucky law prohibited Black people from testifying against white people, the local U.S. Attorney moved the case from state to federal court for prosecution. ${ }^{46}$ The government secured murder convictions and death sentences against the defendants. ${ }^{47}$ However, Kentucky appealed the case to the U.S. Supreme Court. Despite the egregious nature of the crime, at issue before the Court was a relatively straightforward question of federalism - whether the federal court had jurisdiction over a violation of Kentucky law. ${ }^{48}$ By a 6-2 vote, the Court reversed the convictions and death sentences, signaling that the Court was unwilling to make good on the aspirational sentiments

42. Frederick Douglass, Reconstruction, ATL. MonthLy, Dec. 1866, at 50.

43. 80 U.S. 581 (1871).

44. See id. at 585.

45. See Murder. Particulars of the Late Tragedy in Lewis County, CourIER-J., Sept. 9, 1868, at 3 (noting that the coroner collected "the dying declarations of the negro, Richard Foster").

46. See Blyew, 80 U.S. at 591.

47. Additional evidence included

that a short time previous to the murder, Kennard was heard to declare, in presence of Blyew, "that he (Kennard) thought there would soon be another war about the $\mathrm{n}[* * *]$ ers; that when it did come he intended to go to killing $\mathrm{n}[* * *]$ ers, and he was not sure that he would not begin his work of killing them before the war should actually commence.'

Id. at 585 .

48. See id. at 590. 
Congress had advanced in Reconstruction. Instead, the Court's hypertechnical interpretation of Kentucky law undermined the Civil Rights Act's purpose at the expense of Black lives. ${ }^{49}$ In his dissent, Justice Joseph Bradley chastised the majority for "a view of the law too narrow, too technical, and too forgetful of the liberal objects it had in [mind]," namely, to provide judicial redress to Black people when state and private actors deprived them of their civil rights. ${ }^{50}$

The Court's decision in Bylew severely truncated the Act's ability to hold state officials criminally accountable for preventing Black people from exercising their basic rights. ${ }^{51}$ Beyond devastating the Foster family's loved ones, the decision sent a message to Black people throughout the nation: the law was not intended to protect Black people from harm. As scholar Dorothy Roberts explained, "a campaign of white supremacist terror, laws, and policies ... effectively nullified the [Reconstruction] Amendments and replaced abolition with Jim Crow as the constitutional regime." ${ }^{52}$ The Court's early evisceration of the Civil Rights Act during Reconstruction prevented it from being a viable tool to provide redress to Black victims of police violence into the twentieth century. ${ }^{53}$ Subsequent Court decisions then continued to narrow the path to redress.

\section{RECONSTRUCTION REDUX: 18 U.S.C. § 242}

Today, Section 2 of the Civil Rights Act of 1866 lives on as 18 U.S.C. $\S 242,{ }^{54}$ making it a criminal offense for a person acting under color of

49. See id. at 593 (holding that the surviving witnesses were "not persons affected" under the law and therefore the lower federal court lacked jurisdiction to indict the defendants, implying that only the murdered victims were "persons affected" under the Act's language).

50. See id. at 599 (Bradley, J., dissenting).

51. See Robert D. Goldstein, Bylew: Variations on a Jurisdictional Theme, 41 STAN. L. REv. 469, 475 (1989) (explaining that the Court's holding in Bylew cut short a full understanding and appreciation of the Civil Rights Act of 1866's jurisdictional power, resulting in Bylew "never be[ing] part of the established canon of civil rights texts").

52. Roberts, Abolition Constitutionalism, supra note 38, at 8-9 (citing the Civil Rights Act of 1866).

53. For instance, between 1866 and 1939, the DOJ brought only two cases under Section 242: one in 1882 and the other in 1911. See U.S. COMM'N ON C.R., JUSTICE: 1961 Commission ON CIVIL Rights RePORT 45 (1961).

54. In relevant part,

[w]hoever, under color of any law ... willfully subjects any person ... to the deprivation of any rights, privileges, or immunities secured or protected by the Constitution or laws of the United States . . on account of such person being an alien, or by reason of his color, or race ... shall be fined under this title or imprisoned not more than one year, or both .... 
state law or custom to deprive a citizen of their civil rights. ${ }^{55}$ In 1945 , the Court dealt Section 242's enforceability a blow in Screws v. United States. $^{56}$ In January 1943, police officers in Georgia arrested a young, Black auto mechanic, Bobby Hall, for allegedly stealing a tire. ${ }^{57}$ After handcuffing Mr. Hall and transporting him to the courthouse square, the Baker County sheriff and two officers beat Mr. Hall with their fists and "a solid-bar blackjack about eight inches long and weighing two pounds." 58 The officers "continued to beat [Mr. Hall] from fifteen to thirty minutes until he was unconscious" and then deposited him in a jail cell. ${ }^{59}$ Someone summoned an ambulance, but Mr. Hall never regained consciousness, dying at the hospital shortly thereafter. ${ }^{60}$ In reversing the officers' convictions under the amended Civil Rights Act, the Court held that the jury instruction regarding the officers' requisite intent was improper. ${ }^{61}$ The Court explained that "the jury should have been ... instructed that it was not sufficient that petitioners had a generally bad purpose" when beating Mr. Hall to death; rather, the jury needed to find that the officers "had the purpose to deprive" Mr. Hall of his "constitutional right . . . to be tried by a court rather than by ordeal." 62

Since Screws, the government must prove that the defendant acted not merely with malice but "in open defiance or in reckless disregard of a constitutional requirement which has been made specific and definite." ${ }^{63}$ Section 242's specific intent requirement is higher than the general intent required in most criminal cases. ${ }^{64}$ Said another way, the

18 U.S.C. $\$ 242$ (1996).

55. See Adickes v. S.H. Kress \& Co., 398 U.S. 144, 166 n.36 (1970) ("Section 242 of 18 U.S.C. is the direct descendant of $\S 2$ of the 1866 Civil Rights Act.").

56. 325 U.S. 91 (1945).

57. See id. at 92.

58. $I d$.

59. Id. at 93.

60. See id.

61. See id. at 106-07.

62. Id. at 107.

63. Id. at 105; see also United States v. Lanier, 520 U.S. 259, 264 (1997) (explaining that Section 242 prohibits the willful depravation of constitutional rights); United States v. Proano, 912 F.3d 431, 442 (7th Cir. 2019) (stating that "Section 242 is a specific-intent crime" and citing Screws, 325 U.S. 91, noting that at the time, Section 242 "sat in a different part of the U.S. Code").

64. See Eric A. Johnson, Rethinking the Presumption of Mens Rea, 47 WAKE FOREST L. REV. 769, 789 (2012) (explaining that federal and state courts presume that the mens rea presumption requires '"general criminal intent' as opposed to 'specific intent"'). 
defendant must violate a person's right and intend to do so. ${ }^{65}$ In the context of police use of force, the constitutional right in question is usually an individual's right to be free from excessive force derived from the Fourteenth Amendment's Due Process Clause. ${ }^{66}$ The government can also allege that an officer violated a person's Fourth Amendment right, which prohibits law enforcement from using excessive or deadly force to apprehend a person absent necessity or probable cause of a threat of death or serious bodily injury to the officer or others. ${ }^{67}$

During the early Civil Rights Movement, DOJ received information regarding potential Section 242 violations in various ways - individual complaints, FBI investigations, and newspaper reports describing egregious police conduct. ${ }^{68}$ Although the practice was unofficial, DOJ tended to ignore newspaper reports about police violence, claiming that reports from Black newspapers "regularly treat[ed] civil rights stories in a sensational manner." ${ }^{69}$ DOJ's dismissal of Black newspaper reporting meant the federal agency effectively ignored media reporting of police violence against Black people because Black newspapers were often the only media covering it. ${ }^{70}$ The combination of the high burden of proof and the government's reticence to investigate and bring Section 242 prosecutions defanged the

65. Similarly, in Section 1983 cases - the civil parallel to Section 242 - the Court only finds liability where "every reasonable officer would understand that what he is doing violates" the plaintiff's civil rights. Jamison v. McClendon, 476 F. Supp. 3d 386, 404 (S.D. Miss. 2020) (citing Ashcroft v. al-Kidd, 563 U.S. 731, 741 (2011)).

66. U.S. CONST. amend. XIV, $\$ 1$ ("[N]or shall any State deprive any person of life, liberty, or property, without due process of law ....").

67. See Tennessee v. Garner, 471 U.S. 1, 7 (1985).

68. See U.S. COMM'N ON C.R., supra note 53, at 57-58.

69. Id. at $58 \mathrm{n} .118$ (citing discussions with DOJ attorneys regarding failure to investigate case).

70. See, e.g., Gene Roberts \& Hank Klibanoff, The Race Beat: The Press, THE Civil Rights Struggle, and THE Awakening of a Nation 5-6 (2006) (explaining that the mainstream press did not report on "racism in America," leaving the reporting to Black newspapers and "a handful of liberal southern editors" and resulting in "an astonishing ignorance about" the condition of Black people in America). For instance, in Alabama, established Black newspapers like the Birmingham World served as a trusted source for Black Alabamians about current events in the state and world, especially its coverage of the Civil Rights Movement. See How the Media Covered the Civil Rights Movement: Black Newspapers, ALA. PuB. RADIO (Dec. 11 , 2013), https:/www.apr.org/post/how-media-covered-civil-rights-movement-black-newspaper s, [https://perma.cc/VQE7-RTTW] ("[W]hen it came to coverage of events surrounding the Civil Rights Movement, there was little if any coverage at all. Take the Montgomery Bus Boycott as an example. 'The New York Times basically missed the story'...."). 
aspirationally powerful Reconstruction law. ${ }^{71}$ By the early 1960 s, the U.S. Commission on Civil Rights described Section 242 as an obscure piece of legislation, and "a weak instrument for bringing [violators] to justice." 72

The legal system's failure to vigorously combat the deprivation of Black people's civil rights reverberates today. DOJ continues to underutilize Section 242 as a means of redress to victims of police violence. ${ }^{73}$ Today, federal prosecutors charged with bringing Section 242 cases still pursue only a small fraction of the complaints they receive. ${ }^{74}$ For instance, between 1985 and 2001, out of an average of over 8,000 annual complaints people filed with DOJ, the agency brought an average of 58 cases per year. ${ }^{75}$ Between 1990 and 2019, that average decreased to 41 cases per year. ${ }^{76}$ A Syracuse University study reviewing Section 242 complaints between 1986 and 2003 found that DOJ secured convictions in less than $1 \%$ of the complaints it received. ${ }^{77}$

Federal administrations took a hands-off approach to federal criminal prosecutions involving the deprivation of someone's civil rights, deferring instead to state and local prosecutors. ${ }^{78}$ For example,

71. See Lee \& Ifill, supra note 13, at 274-77 (describing the structural obstacles in place that prevent DOJ from prosecuting police excessive force cases under Section 242).

72. U.S. COMM'N ON C.R., supra note 53, at 45.

73. See Brian R. Johnson \& Phillip B. Bridgmon, Depriving Civil Rights: An Exploration of 18 U.S.C. 242 Prosecutions 2001-2006, 34 CRIM. JUST. Rev. 196, 20405 (2009) (noting that Section 242 "prosecutions are a relatively rare event").

74. See id. Cases where DOJ has criminally prosecuted police officers tend to constitute highly publicized examples of law enforcement officials blatantly violating someone's civil rights. These include cases against the Mississippi officers who murdered three civil rights volunteers, Michael Schwerner, James Chaney, and Andrew Goodman, in 1964, see United States v. Price, 383 U.S. 787 (1966); the Los Angeles Police Department officers who beat Rodney King in 1991, see Koon v. United States, 518 U.S. 81 (1996); and the New York City police officers who viciously sodomized Abner Louima with a broom stick in 1997, see United State v. Volpe, 78 F. Supp. $2 d 76$ (E.D.N.Y. 1999).

75. See Johnson \& Bridgmon, supra note 73, at 199-200.

76. See Police Officers Rarely Charged for Excessive Use of Force in Federal Court, TRAC REPS. (June 17, 2020), https:/trac.syr.edu/tracreports/crim/615/\#f1 [https://perma.ce/4PCW-FBCR].

77. See Johnson \& Bridgmon, supra note 73, at 200 (explaining that the Transactional Records Access Clearinghouse at Syracuse University analyzed 43,331 complaints, which resulted in 423 convictions and 267 acquittals).

78. See Paul Hoffman, The Feds, Lies, and Videotape: The Needs for Effective Federal Role in Controlling Police Abuse in Urban America, 66 S. CAL. L. Rev. 1453, 1492 (1993) (describing DOJ's failure to prosecute police excessive force cases during the Reagan and Bush I Administrations); see also Police Brutality: Hearings Before the Subcomm. on Civ. and Const. Rts. of the H. Comm. on the Judiciary, 102d Cong. 
in 1991, during congressional hearings after police officers beat Rodney King, Assistant Attorney General John Dunne testified that federal prosecutors were "not the front line troops in combatting instances of police abuse." 79 Instead, he explained that that "role properly lies with the internal affairs bureaus of law enforcement agencies and with State and local prosecutors." ${ }^{80}$ Dunne then referred to the federal enforcement program, which includes Section 242 prosecutions, as "more of a backstop . . . to these other resources." The reality is that state and local officials are still hesitant to investigate and prosecute law enforcement officials for their unlawful conduct. ${ }^{82}$ As the late Representative John Conyers pointed out in response, "[i]n many of these small cities, nobody wants the grief of going up against the local law enforcement." ${ }^{83}$ Focusing on longstanding police brutality in Los Angeles, Representative Maxine Waters implored federal intervention where the "city council [is] either intimidated or somehow feels that it does not have the oversight responsibility to do anything[,] . . . where [the city] appear[s] to have a police department that answers to no one[ and] where the incidents [of police brutality] over the years continue to pile up." 84

As scholar Stephen Carter explained, the legal system recognizes two types of people when criminal conduct occurs: victims and Black people. ${ }^{85}$ Extending this rationale to determining criminal culpability of law enforcement officials, the legal system recognizes two types of people: criminals and police officers. ${ }^{86}$

31 (1991) |hereinafter Police Brutality Hearings| (explaining that DOJ does not pursue prosecution if state or local officials adequately responded).

79. Police Brutality Hearings, supra note 78, at 3 (statement of John R. Dunne, Assistant Att'y Gen.).

80. Id.

81. Id.

82. See, e.g., Kelly M. Hogue, When an Officer Kills: Turning Legal Police Conduct into Illegal Police Misconduct, 98 Tex. L. Rev. 601 (2020); Asit S. Panwala, The Failure of Local and Federal Prosecutors to Curb Police Brutality, 30 FordHAm URB. L.J. 639, 651 (2003); Philip M. Stinson ET AL., NAt'l Inst. Just., Police Integrity Lost: A STUDY OF LAW ENFORCEMENT OFFICERS ARRESTED 2 (2016), https://scholarworks.bgsu.edu/cgi/viewcontent.cgi?article=1062\&context=crim_just_p ub [https://perma.cc/Z4CV-5PBX].

83. Police Brutality Hearings, supra note 78, at 33.

84. Id. at 36.

85. See Stephen L. Carter, When Victims Happen to Be Black, 97 YALE L.J. 420, 447 (1988).

86. See generally Levine, supra note 16, at 1464-77 (describing unique privileges and procedural protections the law provides to police officers when they are suspected of engaging in criminal conduct). 


\section{ABOLITIONIST FRAMEWORK}

Despite Congress's aspirational goals during Reconstruction, the Civil Rights Act of 1866 and its contemporary analog have been ineffective at delivering justice to victims of police violence. Revolutionary at the time, the Act sought to create redress for Black people who experienced harm at the hands of state actors. However, the social, economic, and political ordering of this nation has long relied upon the subordination of Black people. ${ }^{87}$ Enabling redress disrupts this order. Understood in this way, the Court's narrow interpretation and the government's underenforcement of the statute are predictable responses because they maintain the social order, with Black people in a subordinate position. The criminal legal system cannot deliver justice to Black victims of state violence because it is unable to shake the structural racism it was built upon. Knowing this frees us "to imagine and implement racial strategies that can bring fulfillment and even triumph." 88 Instead of relying on the criminal legal system for redress in individual cases of police misconduct, this Essay calls for victims of police violence to look toward abolition. The harm that an individual police officer renders on a Black person often reverberates throughout a much larger community of Black people. ${ }^{89}$ Rather than try to seek a criminal conviction against a single officer, abolition allows us to begin a process that has the potential to bring redress, healing, and resolve to whole communities of Black people.

87. See, e.g., Derrick Bell, Faces at the Bottom of the Well: The PERMANENCE OF RACISM 8 (1992) ("The critically important stabilizing role that blacks play in this society constitutes a major barrier in the way of achieving racial equality. Throughout history, politicians have used blacks as scapegoats for failed economic or political policies."); DerRick Bell, Silent CovenANTS: BROWN V. BOARD OF EDUCATIONAND THE UNFULFILLED HOPES FOR RACIAL REFORM 83 (2004) ("[W]hite people desperately need[] . . black people - or most blacks - in a subordinate status in order to sustain ... the ... preferential treatment to which every white person is granted ... ."); Kimberlé Williams Crenshaw, Race, Reform, and Retrenchment: Transformation and Legitimation in Antidiscrimination Law, 101 HARV. L. REV. 1331, 1362 (1988) (explaining "that the relatively subordinate status of Blacks serves a stabilizing function in this society").

88. Bell, supra note 24 , at 79.

89. See, e.g., Jacob Bor et al., Police Killings and Their Spillover Effects on the Mental Health of Black Americans: A Population-based, Quasi-Experimental Study, 392 LANCET 302, 302 (2018) (finding that police killings of unarmed Black people adversely affect the mental health of Black Americans not directly impacted by the incident); see also Desmond Ang, Wider Effects of Police Killings in Minority Neighborhoods, ECONOFACT (June 24, 2020), https://econofact.org/wider-effects-of-police-killings-in-minority-neighborhoods [https://perma.ce/TB44-ZLAT] (showing that high-profile, officer-involved killings of unarmed ethnic minorities can negatively impact the academic achievement, school attendance, and crime reporting in the neighborhoods where they occur). 
Abolition is a broad theoretical framework that renounces incarceration as the remedy to social problems and embraces preventative and restorative solutions to harm..$^{90}$ The modern prison abolition movement coalesced in 1997 when Angela Y. Davis and other activists formed Critical Resistance, an organization devoted to abolishing the prison system. ${ }^{91}$ In 2003, Professor Davis published Are Prisons Obsolete?, which called out society's reliance on a system driven more by capitalism and anti-Black racism than ensuring safety. ${ }^{92}$ Over the past two decades, a widening group of activists, organizers, and scholars have adopted abolitionist rhetoric and tactics to critique this nation's reliance on prisons and the related entities that funnel people into prisons - police, prosecutors, and, more broadly, the criminal legal system. ${ }^{93}$ Instead of reforming the system, abolition calls for dismantling it. ${ }^{94}$ This collective criticism has begun to inspire and inform policymaking and legislative action within the criminal legal

90. See Angela Y. Davis, Are Prisons Obsolete? 43-46 (2003).

91. See History, CRITICAL RESISTANCE, http://criticalresistance.org/about/history [https://perma.ce/5Q5M-BRPG] (last visited Feb. 7, 2021) ("Critical Resistance was formed in 1997 when activists challenging the idea that imprisonment and policing are a solution for social, political, and economic problems came together to organize a conference that examined and challenged what we have come to call the prison industrial complex (PIC)."').

92. See DAVIS, supra note 90.

93. See generally Angela Y. Davis, ABolition Democracy (2005); KATHERINE Franke, RePair: Redeeming the Promise of Abolition (2019); RUTH WILSON Gilmore, Golden Gulag: Prisons, Surplus, Crisis, and OpPosition IN Globalizing California (2007); Alex Vitale, The End of Policing (2017); Developments in the Law, 132 HARV. L. REV. 1568 (2019) (this issue was devoted to prison abolition with works by Dylan Rodríguez, Allegra McLeod, Angel E. Sanchez, Patrisse Cullors, and Dorothy Roberts); Akbar, Toward a Radical Imagination of Law, supra note 22; Paul Butler, The System Is Working the Way It Is Supposed To: The Limits of Criminal Justice Reform, 104 GEO. L.J. 1419 (2016); César Cuauhtémoc García Hernández, Abolishing Immigration Prisons, 97 B.U. L. Rev. 245 (2017); Hasbrouck, supra note 17; McLeod, supra note 18; Alexandra Natapoff, Atwater and the Misdemeanor Carceral State, 133 HARv. L. REv. F. 147 (2020); Jocelyn Simonson, The Place of "The People" in Criminal Procedure, 119 Colum. L. Rev. 249 (2019); Dan Berger, Mariame Kaba \& David Stein, What Abolitionists Do, JACoBIN MAG. (Aug. 24 , 2017) https:/www.jacobinmag.com/2017/08/prison-abolition-reform-mass-incarceration [https://perma.ce/VKL4-GMND]; Mariame Kaba, Yes, We Mean Literally Abolish the Police, N.Y. Times (June 12, 2020), https:/www.nytimes.com/2020/06/12/opinion/sunday/floyd-abolish-defund-police.htm 1 [https://perma.cc/RKX4-5ZB9].

94. See Nicole Smith Futrell, The Practice and Pedagogy of Carceral Abolition in a Criminal Defense Clinic, 45 N.Y.U. REv. L. Soc. CHANge (forthcoming 2021) ("History has demonstrated that overlaying reforms onto an existing infrastructure does nothing to eradicate the underpinnings of racism and social control that simply mutate over time."). 
system. ${ }^{95}$ The Black Lives Matter uprisings in the spring and summer of 2020 have added greater urgency to these conversations and efforts. ${ }^{96}$

The abolitionist framework encourages us to consider how this nation's history of slavery helped shape today's racialized carceral state and invites us to imagine a future without carceral punishment. ${ }^{97}$ It begins with the premise that the criminal legal system replaced the institution of slavery as the primary means of controlling Black people and low-income people to maintain white supremacy and capitalism. ${ }^{98}$ It acknowledges that the current social order depends on policing, prosecution, and prisons to perpetuate racial and economic inequality. So, instead of turning toward the criminal legal system to prosecute individual police officers who have engaged in brutality, abolition invites us to think critically and dynamically about the conditions that caused the harm and about restorative solutions that could address the long history of racial violence against Black people. ${ }^{99}$ This reorientation enables us to reimagine systems capable of dismantling

95. See, e.g., Rachel La Corte, Washington Senate Passes Death Penalty Repeal Bill, SEATtLe Times (Feb. 16, 2019, 12:01 PM), https://www.seattletimes.com/seattle-news/bill-to-abolish-death-penalty-in-washingto n-passes-state-senate/ [https://perma.cc/T2YS-MDWV] (describing proposed legislation after a state supreme court ruling finding the death penalty unconstitutional under state law due to racial discrimination in State v. Gregory, 427 P.3d 621 (Wash. 2018)).

96. See, e.g., Ending Qualified Immunity Act, H.R. 7085, 116th Cong. (2019); Enhance Law Enforcement Integrity Act, S.B. 20-217 (Colo. 2020); H.R. HF1, 91st Leg., 2d Spec. Sess. (Minn. 2020); Dahlia Bazzaz \& Hannah Furfaro, Police Presence at Seattle Public Schools Halted Indefinitely, Seattle Times (Aug. 12, 2020, 11:35 AM),

https://www.seattletimes.com/education-lab/police-presence-at-seattle-public-schoolshalted-indefinitely/ [https://perma.cc/C86W-WT4E]; Saja Hindi, Colorado Among First in U.S. to Pass Historic Police Reforms Following Protests, DenVER Post (June 13, 2020, 5:40 https://www.denverpost.com/2020/06/13/colorado-police-reform-bill-passes-legislatur e/ [https://perma.cc/F7ER-HCVU] (stating that legislation included abolishing qualified immunity as an affirmative defense to officers facing civil liability for unlawful conduct); Vanessa Romo, Minneapolis Council Moves to Defund Police, Establish 'Holistic' Public Safety Force, NPR (June 26, 2020, 8:14 PM), https://www.npr.org/sections/live-updates-protests-for-racial-justice/2020/06/26/88414 9659/minneapolis-council-moves-to-defund-police-establish-holistic-public-safety-for c [https://perma.cc/WR8U-E5EM].

97. See Roberts, Abolition Constitutionalism, supra note 38.

98. See id. at 4.

99. See McLeod, supra note 18, at 1207 ("[A]n abolitionist ethic, in virtue of its structural critique of penal practices, is oriented toward displacing criminal law as a primary regulatory framework ...."). 
white supremacy, redistributing resources to prevent harm, and advancing remedies that do not center on carceral punishment. ${ }^{100}$

\section{ABOLITIONIST SOLUTIONS}

Abolition enables solutions tailored to the harms experienced. As such, the remedy sought may differ depending on the nature and extent of the harm, and the desires of the person (or communities) who experienced it. Although instances of excessive police violence often involve individual officers and people, the harm experienced can spread to entire communities over time, as was the case in the Chicago police torture cases ${ }^{101}$ and in Los Angeles after officers beat Rodney King. ${ }^{102}$ Other cases may involve relatively minor individual harm, but the pervasiveness and the racially targeted nature of the harm can result in widespread impact on entire communities of color, such as with the New York City Police Department's racially discriminatory implementation of stop and frisk. ${ }^{103}$

Abolition allows us to think expansively about what might repair the harms that people experience at the hands of law enforcement officials and what might prevent future harm. ${ }^{104}$ Given the white supremacy embedded in the criminal legal system, it is misguided to believe criminal law is capable of holding individual law enforcement officials criminally accountable for their unlawful conduct against people, particularly Black people. Police violence against Black people is part of the history, structure, and very nature of policing in this country. ${ }^{105}$

100. See id. at 1208 ("Displacing criminal regulation and replacing it with other regulatory forms entails a primary orientation toward proliferating substitutive approaches to address social problems, root causes, and interpersonal harm through institutions, forms of empowerment, and regulatory approaches separate and apart from the criminal law.").

101. See infra Section IV.A.

102. See Lee \& Ifill, supra note 13, at 256-57 (describing "outrage among communities of color across the country that had suffered from police abuse" after the acquittal of the officers who beat Rodney King).

103. See, e.g., Floyd v. City of New York, 959 F. Supp. 2d 540 (S.D.N.Y 2013) (finding that the New York City Police Department's (NYPD) stop-and-frisk practices, whereby NYPD officers engaged in approximately 5 million searches over a ten-year period, were racially discriminatory in violation of the Equal Protection Clause of the Fourteenth Amendment where $84 \%$ of those stopped were Black or Latinx, and despite stated purpose of the policy, police recovered weapons and contraband only $2 \%$ of the time).

104. See Akbar, Toward a Radical Imagination of Law, supra note 22, at 412 ("[E]ven when the scale of our critique is large, our visions for change are often too small.").

105. See Devon W. Carbado \& Patrick Rock, What Exposes African Americans to Police Violence?, 51 HaRv. C.R.-C.L. L. REv. 159, 161-64 (2016); see also Alice 
Moreover, police serve as the enforcement arm of the criminal legal system, creating an inherent conflict when prosecutors then attempt to enforce the law against them. ${ }^{106}$ Thus, the question should not be why does the criminal legal system fail to deliver justice to victims of police violence? Instead, we must ask, what can repair the harm that police officers render, and what can prevent future harm? An abolitionist framework allows us to look beyond the carceral system toward models that would enable repair and prevent future harm. Examples of these models already exist in communities that have experienced police violence. This Part describes two kinds of abolitionist efforts reparations and divestment and reinvestment - and offers suggestions for how to expand them to other localities.

\section{A. Reparations}

In his Second Treatise, John Locke explained that besides criminal law, which provides for punishment of the person who has committed a transgression, the person who experienced the resulting injury has "a particular right to seek reparation." 107 Although our adversarial criminal legal system is well-equipped to mete out punishment, it is not designed to enable repair. To be clear, reparations are not about punishing the actor, like punitive damages in tort. Instead, reparations are intended to repair harm rendered by the state to a class or group of people. The Movement for Black Lives defines "reparations" as "the act or process of making amends for a wrong." 108 The United Nations recommended that " $[\mathrm{r}]$ eparation should be proportional to the gravity of the violations and the harm suffered." 109 Examples of reparations include money Germany paid to survivors of the Holocaust, ${ }^{110}$ the United States paid to Japanese Americans after confiscating their property and confining them in internment camps during World War

Ristroph, The Thin Blue Line from Crime to Punishment, 108 J. CRIM. L. \& CRIMINOLOGY 305, 306-07 (2018) (describing the inherently violent nature of policing). See generally Paul Butler, Chokehold: Policing Black Men (2017); Stevenson, supra note 18; Akbar, An Abolitionist Horizon, supra note 26; Hasbrouck, supra note 17; Roberts, Constructing a Criminal Justice System, supra note 14; Simonson, supra note 26.

106. See Levine, supra note 16 , at 1447.

107. John Locke, SECOND TrEatise 7 (J.W. Gough ed., 1948).

108. Andrea Ritchie et al., Reparations Now Tool Kit, MovemenT For Black

LIVES 25 (2019),

https://m4bl.org/wp-content/uploads/2020/05/Reparations-Now-Toolkit-FINAL.pdf [https://perma.cc/2VVN-VNXV].

109. G.A. Res. 60/147, đ 15 (Mar. 21, 2006).

110. See Tony Judt, Postwar: A History of Europe Since 1945, at 271 (2005). 
II, ${ }^{111}$ and Florida paid to survivors of the Rosewood Massacre, in which state officials razed the predominately Black town of Rosewood. ${ }^{112}$ Fundamentally, reparations are about addressing injustice. It was for these reasons that the survivors of police torture in Chicago demanded and received monetary and other forms of reparations from the City.

During the 1970s and 1980s, officers in the Chicago Police Department systematically tortured over 100 Black men, subjecting them to beatings, electric shocks (including to their genitals), mock executions, virulent racial slurs, and other abuse. ${ }^{113}$ Detective Jon Burge directed the torture with the knowledge of superior officials, including the elected State's Attorney of Cook County, and without intervention. ${ }^{114}$ Although prosecutors later secured a criminal conviction against Burge, the widespread damage the Chicago Police Department inflicted on individuals, their loved ones, and the public's trust in law enforcement necessitated repair. The process to repair was long and arduous, involving grassroots organizers, activists, Black lawyers, and educators; multiple city officials resisted, repeatedly, before reaching an agreement. ${ }^{15}$

The activists agreed to identify the relief sought as "reparations" to recognize the longstanding anti-Black racism in Chicago's policing, link the police torture with the brutality of slavery, and help enable "a true and complete narrative through which torture victims could seek acknowledgement and remedies." 116 The reparations included monetary compensation to the victims of torture, ${ }^{117}$ psychological counseling for all torture survivors, an official apology, tuition-free education at a local college to torture survivors and their families, a requirement that Chicago public schools teach students about the torture cases, and the construction of a public memorial to torture victims. ${ }^{118}$ The contours of reparations in the Chicago police torture

111. See Civil Liberties Act of 1987, H.R. 442, 100th Congress (1988); Robert Westley, Many Billions Gone: Is It Time to Reconsider the Case for Black Reparations?, 40 B.C. L. REV. 429, 449-53 (1998) (describing the U.S. government's internment of Japanese Americans and subsequent legislation to provide reparations to survivors).

112. See Rosewood Bill, H.B. 591, 1994 Leg., Reg. Sess. (Fla. 1994); Westley, supra note 111, at 452 (mentioning the Rosewood Massacre and Florida legislature's subsequent grant of reparations to survivors).

113. See G. Flint Taylor, The Long Path to Reparations for the Survivors of Chicago Police Torture, 11 Nw. J.L.\& SOC. POL'Y 330, 335 (2016).

114. See id. at 330.

115. See id. at 340-41.

116. Id. at 338 .

117. The City agreed to pay $\$ 5.5$ million to the surviving victims. See id. at 348-49.

118. See S.R. 2015-256, 99th Gen. Assemb. (Ill. 2015). 
cases were uniquely fitted to repair the harms specific to those men and the broader Black community in Chicago. Given abolitionism's expansive framework, local actors have the power to envision what responses, amount of compensation, and actions would begin the process toward healing. Relying on the Chicago police torture reparations process and others, the Movement for Black Lives authored a toolkit to guide organizers on how to conceive of, demand, and obtain reparations. ${ }^{119}$

\section{B. Divest and Reinvest}

Abolition also allows for a combination of divestment and reinvestment to help prevent future harm. Like reparations, divestment and investment is a solution directed at an audience broader than the parties directly impacted by police violence. Allegra McLeod called this "justice reinvestment," whereby state actors reduce spending on factors that support the carceral paradigm and then reinvest those funds "in other . . . concepts of justice and prevention with more expansive meaning." 120 For example, Amna Akbar suggested a series of divestment: "[S]uspending the use of paid administrative leave for police under investigation; withholding pensions and refusing to rehire police involved in the use of excessive force; making police liable for misconduct settlements; [and] limiting and withdrawing from participation in police militarization programs." 121 She then combined these suggestions with areas for reinvestment, such as "prioritizing spending on community health, education, and affordable housing." 122 In this way, the focus is on "strengthening the social (rather than the criminal) arm of the state out of concern for justice" and advancing preventive justice to address some of the underlying social issues that contribute to harm to prevent future harm from occurring. ${ }^{123}$ The strategy to divest and reinvest gained renewed national attention in the wake of George Floyd's murder when activists throughout the country demanded the state

119. See Ritchie et al., supra note 108 , at 66-72.

120. McLeod, supra note 18 , at 1225.

121. Akbar, An Abolitionist Horizon, supra note 26, at 1826.

122. Id.

123. McLeod, supra note 18 , at 1225 . To address racial inequality and police violence, the National Advisory Commission on Civil Disorders, widely known as the "Kerner Commission," suggested something akin to justice reinvestment. In 1968, the Kerner Report recommended "a national agenda to address and remedy the entrenched racial inequality in employment, education, the welfare system, and housing." Lee \& Ifill, supra note 13, at 258. 
defund police while simultaneously calling for reinvestment of these funds into programming, services, and opportunities to prevent the occurrence of harm. ${ }^{124}$

Divestment and reinvestment are already occurring in local communities. L.A. for Youth is a nonprofit organization and movement centered on building a positive future for young people in Los Angeles, California. ${ }^{125}$ The organization's central aim is a campaign to redirect monetary resources away from policing and into preventative and interventionist strategies, including employment opportunities for young people to provide them with skills to enter the workforce. ${ }^{126}$ The campaign calls for the City to divest at least $5 \%$ of Los Angeles's law enforcement budget. ${ }^{127}$ It then identifies a specific vision for reinvestment, including creating and establishing a youth leadership board, providing 15,000 jobs and paid internships for young people, funding youth development centers, hiring and training community interventionists and peacebuilders, and providing free public transit passes to all young people in the City. ${ }^{128}$ Each of these factors aims to reduce opportunities for young people to engage in harmful conduct while also equipping them with tools, skills, and pathways to productive behavior.

\section{CONCLUSION}

Beyond reparations and divestment and reinvestment, abolition allows for reckoning and reconciliation as avenues for addressing harm. Other countries have engaged in such work following widespread harm. ${ }^{129}$ Bryan Stevenson, Founder and Director of the

124. See, e.g., Invest-Divest, Movement FOR BLACK LIVEs, https:/m4bl.org/policy-platforms/invest-divest/ [https://perma.cc/ZL8X-BMXN] (last visited Feb. 8, 2021).

125. See L.A. FOR YOUTH, http://www.laforyouth.org/ [https://perma.ce/EBW9-WDBP] (last visited Feb. 8, 2021); see also BUILDING A Positive Future For LA's Youth: Re-IMAgININg PUblic SafeTy for the City of Los ANGEles WITH AN INVESTMENT IN YOUTH DEVELOPMENT (2016) [hereinafter BUILDING A POSITIVE Future FOR LA's YOUTH], https:/www.acesconnection.com/g/los-angeles-aces-connection/resource/las-youth-bu ilding-a-positive-future-reimagining-public-safety-with-an-investment-in-youth-devel opment-pdf [https://perma.cc/FH56-72EB].

126. See BuILding a Positive Future For LA's Youth, supra note 125, at 4.

127. See id.

128. See id.

129. For example, after apartheid ended in 1995, South Africa formed a Truth and Reconciliation Commission (TRC). The TRC held public hearings to begin the process of healing, providing a forum for victims of state violence and white supremacy to tell their stories and for the perpetrators of harm to admit their actions. See Ereshnee 
Equal Justice Initiative (EJI), is spearheading a campaign calling for acknowledgement of racial terrorism and providing pathways toward reconciliation. ${ }^{130}$ Similarly, Sherrilyn Ifill, President and DirectorCounsel of the NAACP Legal Defense and Educational Fund, Inc., has called for racial reckoning to enable reconciliation of longstanding harms that whole communities of Black people experienced as a result of state-sanctioned violence in the name of white supremacy. ${ }^{131}$ The adversarial criminal legal system - which disfavors assuming responsibility for harm - is ill-equipped to enable reckoning and reconciliation. To meaningfully address harm and prevent it from reoccurring, we must look outside the carceral system. Instead, abolition can provide a pathway toward justice.

Naidu-Silverman, What South Africa Can Teach the U.S. About Reparations, WASH. PosT (June 25, 2019, 6:00 https:/www.washingtonpost.com/outlook/2019/06/25/what-south-africa-can-teach-usabout-reparations/ [https://perma.cc/K88L-UXLS].

130. See National Memorial for Peace and Justice, Equal Just. Initiative, https://museumandmemorial.eji.org/memorial [https://perma.cc/W3DM-H5XR] (last visited Feb. 8, 2021) ("It is EJI's hope that the National Memorial inspires communities across the nation to enter an era of truth-telling about racial injustice and their own local histories.... We work with communities to erect historical markers, organize soil collection ceremonies, and hold essay contests for local high school students to support the development of local, community-led efforts to engage with and discuss past and present issues of racial justice. After active Community Remembrance work, EJI will also collaborate to place a monument - identical to the monument found at the National Memorial - in the community. EJI believes that markers and monuments can help transform our national landscape into a more honest reflection of the history of America and reflect a community's ongoing commitment to truth-telling and racial justice.").

131. See, e.g., SHerrilyn A. Ifill, On the Courthouse Lawn: Confronting the LEGACY OF LYNCHING IN THE 21sT CENTURY 176 (2d ed. 2018) ("[W]e have the opportunity to confront twentieth-century racial violence and begin a long-overdue process of truth-telling and reconciliation."). 


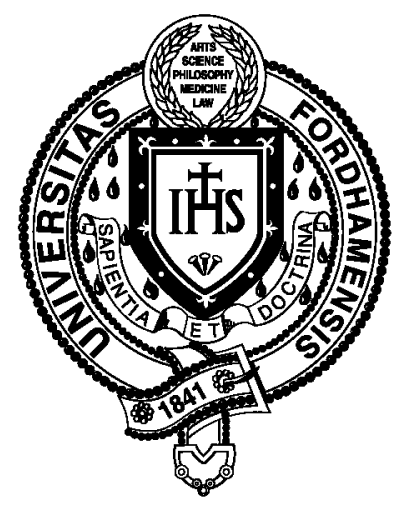

